\title{
CABUL NO INVERNO - VIDA SEM PAZ NO AFEGANISTÃO CABUL NAS PRISÕES
}

Henrique Mercer $^{1}$

Aquilo que uma mulçumana veste não é apenas uma questão de gênero. Ela carrega todo o peso do mundo islâmico ( $p$. $155)$.

O Núcleo de Estudos em Direito Internacional - Condição Feminina, da Universidade Federal do Paraná, colocou em debate, em diversos encontros, questões jurídicas relacionadas com o sistema de proteção aos direitos da mulher. Em uma dessas ocasiões, foi questionado se um sistema nos moldes ocidentais seria ou não efetivo em uma cultura islâmica. Para alimentar o debate, considerou-se oportuna a leitura de Cabul no Inverno: Vida sem Paz no Afeganistão, de Ann Jones.

A autora atuou como voluntária de uma organização nãogovernamental no Afeganistão, a princípio para verificar a situação jurídica das prisioneiras $^{2}$ do presídio Welayat, em Cabul. O livro é o relato dessa experiência, que repercute a realidade do sistema prisional afegão tal como se delineou após a queda do governo talibã. $O$ texto está dividido em três partes: Nas Ruas, Nas Prisões e Nas Escolas. O presente trabalho ater-se-á à segunda parte, Nas Prisões, em vista de seu interesse para o estudo em tela.

A narrativa começa no inverno de 2003. De pronto a autora percebeu que a situação jurídica das prisioneiras era secundária diante das condições desumanas do presídio, que não dispunha de uma infra-estrutura mínima para

\footnotetext{
1 Advogado, estudante livre na Université du Québec à Montreal, membro do NDI e do NUPESUL (UFPR), especialista em Direito Internacional (PUC-PR) e em Diplomacia e Negociações Internacionais (Unibrasil).

2 JONNES, Ann. Cabul no inverno: vida sem paz no Afeganistão. São Paulo: Novo Conceito, 2006, p. 109.
}

Revista Brasileira de Direito Internacional, Curitiba, v.6, n.6, jul./dez.2007 
que vivessem dignamente em seu cárcere. Dificilmente uma jovem prisioneira chegaria aos 35 anos de idade.

Com relação à situação jurídica, constatou que a maioria das 16 mulheres que lá estavam seriam criminosas para os padrões ocidentais. A maior parte era acusada de crimes contra a moralidade pública, tais como cometer zina ${ }^{3}$ (termo que cobre indiscriminadamente sexo extraconjugal tanto consensual como coagido ${ }^{4}$ ); contrair matrimônio "ilegal"; fugir com um homem; fugir de casa; e - por absurdo que pareça - estar perdida na rua. A fuga com um homem sequer é crime, de acordo com o código penal afegão, mas as mulheres são punidas pelo entendimento jurisprudencial de que não fazê-lo poderia encorajar a prática e é função do judiciário manter a sociedade ilibada ${ }^{5}$.

O sistema jurídico afegão, ou melhor, seus operadores, refletem uma convicção do senso comum na cultura local, de que as mulheres mentem, de modo que ninguém lhes dá crédito na sua versão dos fatos.

Outra característica do sistema afegão está em que muitas vezes as mulheres são julgadas e punidas em casa, sem passar pelo judiciário formal ${ }^{6}$. Assim, em Jalalabad, uma cidade tradicionalista, não havia registros de nenhuma mulher presa por zina, pois problemas desse tipo eram resolvidos em família.

A autora estabelece uma relação entre o padrão de comportamento "tradicional" e o "islâmico", a ser observado por uma mulher afegã para preservar a honra e a moral de sua família e a pureza exigida das mulheres no período vitoriano. Ressalta, porém, que o código moral afegão é mais rígido e mais severo ${ }^{7}$.

\footnotetext{
${ }^{3} 13$ das 16 prisioneiras eram acusadas de zina. Um relatório de uma agência internacional sobre as presidiárias em Herat em 2004, computava que $78 \%$ delas estava presa por zina.

${ }^{4} \mathrm{O}$ sexo coagido várias vezes é descrito como prostituição, que a esposa é obrigada a praticar pelo marido e/ou sua família. Ocorre que as mulheres afegãs nem sabem o que é prostituição. Normalmente essa situação de zina, levava a outro crime: fugir de casa e do marido. Ou ainda, casar com um cliente para que ele não peque perante o islã, mas ela acaba incorrendo em outro crime, o de casamento ilegal (JONNES, Ann. Cabul no inverno: vida sem paz no Afeganistão. São Paulo: Novo Conceito, 2006, p.p. 114).

${ }^{5}$ JONNES, Ann. Cabul no inverno: vida sem paz no Afeganistão. São Paulo: Novo Conceito, 2006, p. 118.

${ }^{6}$ JONNES, Ann. Cabul no inverno: vida sem paz no Afeganistão. São Paulo: Novo Conceito, 2006, p. 110-111.

7 JONNES, Ann. Cabul no inverno: vida sem paz no Afeganistão. São Paulo: Novo Conceito, 2006, p. 112.
}

Revista Brasileira de Direito Internacional, Curitiba, v.6, n.6, jul./dez.2007 
A questão que se põe é que no Ocidente os direitos humanos são inerentes ao indivíduo pelo simples fato de ser humano. No Afeganistão, o indivíduo vale quase nada e a mulher nem isso. Para os afegãos, o que importa é a coletividade - a islâmica, a tribo e a família. Portanto, as presidiárias eram acusadas de violar o código moral que mantém coesa a coletividade. $\mathrm{O}$ objetivo da justiça é reparar o dano a essa coesão.

No Afeganistāo não se pune o indivíduo como no Ocidente. O fato das mulheres estarem presas significa não somente que elas estão sendo castigadas, mas principalmente, tem por objetivo mantê-las fora da sociedade e assim, traze-la volta ao seu correto equilíbrio ${ }^{8}$.

O caráter indefinido dos crimes de que as mulheres eram acusadas dá liberdade aos operadores do direito - investigadores, juízes e promotores para especular e decidir casos sem provas empíricas ou até em detrimento delas, com base em atitudes patriarcais, pelas quais sua obrigação não era promover a justiça ou garanti-la a essas mulheres, e sim manter sadia a sociedade, a sociedade patriarcal.

Formalmente, o sistema judiciário afegão está organizado em três níveis: no primeiro ocorrem as investigações iniciais e se proferem as decisões judiciais; no segundo, os recursos são apreciados e investigações adicionais são cumpridas; no último, que é a suprema corte, os recursos são julgados em última instância.

Em cada nível o conservadorismo dos julgadores aumenta, já que, quanto mais elevado o nível em que o juiz atua tanto melhor terá sido sua educação, esta entendida exclusivamente como conhecimento da lei da xaria.

No período comunista o Afeganistão tinha uma corte exclusiva de família, que acabou sendo extinta pelo Talibã, subsistindo apenas em Cabul.

Os promotores apresentam os casos aos juízes que em tese deviam ser imparciais, mas a parcialidade já se reflete na própria composição do judiciário em que, de 2006 juízes, apenas 27 são mulheres.

\footnotetext{
${ }^{8}$ JONNES, Ann. Cabul no inverno: vida sem paz no Afeganistão. São Paulo: Novo Conceito, 2006, p. 117.
}

Revista Brasileira de Direito Internacional, Curitiba, v.6, n.6, jul./dez.2007 
A ré não tem quase nenhuma importância e raramente vai ao próprio julgamento. É apenas notificada da sentença, mas não necessariamente do que foi acusada. As testemunhas femininas também raramente são levadas ao tribunal e, caso seja levadas, são necessárias duas para igualar ao testemunho de um homem, como determina o Corão. As mulheres também não contavam com advogados de defesa até 2004, quando uma ONG começou a treinar advogadas para defendê-las. No sistema afegão não é claro por que um indivíduo deva ter um advogado de defesa, se o que importa é a sociedade, defendida pelo promotor contra esse indivíduo. Aos olhos dos juízes, uma advogada que defende uma "mulher má" nada mais é do que outra "mulher má".

$\mathrm{Na}$ conferência de Bonn em que foi criado o Estado Islâmico Transicional do Afeganistão, foi criado também o Ministério da Mulher do Afeganistão. Para os ocidentais, as ilusões se desvaneceram quando a ministra afirmou que espancar mulheres era um costume normal no Afeganistão e que não seria ela a criar problemas quanto a isso. $O$ grande slogan do Ministério era "Grandes Líderes Têm Grandes Mães"'.

No Afeganistão, portanto, não é ilegal marido bater na mulher ou cometer estupro conjugal. Não existe dispositivo legal sequer contra o estupro, tratado como um subparágrafo do adultério. Quando uma mulher denuncia um estupro, permanece presa por adultério até as investigações determinarem se consentiu com o ato ou não ${ }^{10}$.

O artigo 22(2) da constituição da República Islâmica do Afeganistão, de 4 de janeiro de 2004, determina que "Os cidadãos do Afeganistão - sejam homens ou mulheres - têm direitos e obrigações iguais perante a lei". $\mathrm{Na}$ prática, porém, esse artigo não tem nenhuma efetividade.

O sistema legal do país é complementado infraconstitucionalmente por um código civil, um código penal, práticas tradicionais que são chamadas de direito consuetudinário e um código moral, a xaria, da qual derivam um

\footnotetext{
${ }^{9}$ JONNES, Ann. Cabul no inverno: vida sem paz no Afeganistão. São Paulo: Novo Conceito, 2006, p. 119.

${ }^{20}$ JONNES, Ann. Cabul no inverno: vida sem paz no Afeganistão. São Paulo: Novo Conceito, 2006, p. 132.
}

Revista Brasileira de Direito Internacional, Curitiba, v.6, n.6, jul./dez.2007 
conjunto de leis que classificam os crimes e fixam penas aplicáveis, como kisas (retaliação), diya (pagamento por sangue) e haad (amputação, apedrejamento).

Os códigos novos, elaborados à luz da nova constituição, são claros com relação à igualdade entre homens e mulheres, mas os operadores do direito ainda não estão familiarizados com as novas previsões, havendo julgadores que simplesmente negam a existência da constituição, defendendo a aplicação exclusiva da xaria que, segundo eles, é a única lei do país. Já outros interpretam que a previsão constitucional não significa que homens e mulheres são iguais. Verifica-se, pois, que o problema não é de falta de legislação, mas de ausência de um sistema para apoiá-la e dar-lhe efetividade.

Sendo o princípio da legalidade a espinha dorsal de qualquer governo democrata, um judiciário que não sabe aplicar os novos códigos acaba se configurando uma loteria, onde se aplica o direito mais interessante a quem paga mais. De fato, há mulheres acusadas que têm mais sorte com suas famílias - e mais dinheiro - subornam os agentes do judiciário. Aliás, algumas vêem a advogada de defesa como uma negociadora de propinas.

Essa situação gera igualmente um contra-senso entre as declarações internacionais de proteção aos direitos das mulheres e das crianças assinadas pelo Afeganistão, que encontram respaldo no ordenamento jurídico interno e o funcionamento real do judiciário. Ou seja, são respaldadas teoricamente, mas não na prática.

Outro problema na aplicação do direito reside no fato de que, quando aplicado com base no Corão, isso ocorre em árabe, língua que grande parte dos operadores do direito não domina, de modo que muitas vezes sequer sabem o que se está falando.

O presidente da suprema corte - um clérigo que havia ensinado a lei da xaria durante décadas em uma madraça no Paquistão - entendia, por exemplo, que a lei islâmica era favorável às mulheres, pois concedia a elas todos os direitos de que precisavam e também três privilégios que não são concedidos aos homens: rezar em casa, obedecer a seus maridos e abster-se de cometer más ações. E declina ainda um privilégio extra, que é o fato de os homens irem à jihad para protegê-las.

Revista Brasileira de Direito Internacional, Curitiba, v.6, n.6, jul./dez.2007 
A autora resume o problema citando uma professora de direito da Universidade de Cabul: "A caneta que registra os direitos da mulher está sempre na mão de um homem".

Uma das poucas soluções que a autora encontrou ao dilema sobre a efetividade da Constituição afegã foi a interpretação dada por um eminente acadêmico árabe (ou seja, alguém que domina o idioma do Corão) à previsão constitucional afegã:

\begin{abstract}
A Constituição afegã de 2004 tem precedência sobre qualquer outro tipo de lei no país, incluída a xaria, e que ela acolhe os princípios dos principais documentos internacionais de direitos humanos - isto é, a Declaração Universal dos Direitos Humanos, o Tratado Internacional de Direitos Civis e Políticos e a Convenção sobre a Eliminação de Todas as Formas de Discriminação contra a Mulher (CEDAW) - e especificamente atribui vários deveres ao Estado (incluída ação afirmativa) para garantir que as mulheres obtenham direitos iguais aos dos homens. A constituição também especifica que 'nenhuma lei pode ser contrária às crenças e prescrições da sagrada religião do Islã. Mas é exatamente a inclusão deste artigo (...) que demonstra a suposição constitucional de que os princípios dos direitos humanos, os princípios do Islã e a própria constituição coincidem em consonância justa e harmoniosa ${ }^{11}$.
\end{abstract}

Mesmo no caso de aplicação da lei, isso não ocorreria na maior parte do Afeganistão, porque não há tribunais que pertençam ao sistema judicial do governo central. Isso acontece porque os prédios foram destruídos e os juízes designados para as regiões preferem ficar em Cabul, onde é mais seguro. Em conseqüência, os tribunais de apelação, ao invés de serem formados por três juízes como previsto, são formados por seis ou sete ${ }^{12}$.

Onde a justiça estatal não está presente prevalece a justiça tribal. Por exemplo, no código dos pachtuns (pachtunwali), o assassinato da esposa favorita de um homem custa ao assassino, quatro cópias novas do Corão, quatro mulheres e uma ovelha gorda, que deverão ser pagas à família da assassinada (ou seja, ao marido). Em caso de inadimplemento, o marido terá o direito de matar o assassino de sua esposa. O mesmo ocorre com crimes

\footnotetext{
${ }^{11}$ JONNES, Ann. Cabul no inverno: vida sem paz no Afeganistão. São Paulo: Novo Conceito, 2006, p. 129.

${ }_{12}$ JONNES, Ann. Cabul no inverno: vida sem paz no Afeganistão. São Paulo: Novo Conceito, 2006, p. 130.
}

Revista Brasileira de Direito Internacional, Curitiba, v.6, n.6, jul./dez.2007 
menores. Por exemplo, fazer alguém perder um olho ou uma orelha vale meio assassinato. Já o corte nos genitais de um homem vale dois assassinatos e, via de conseqüência, muito mais ovelhas, mulheres e cópias novas do Corão. No entanto, as mulheres não valem tanto assim vivas. $E$ entre as que valem mortas, são poucas as esposas favoritas.

Corre risco até as mulheres que tenham sido submetidas ao judiciário estatal, recebido condenação e cumprido pena. Quando libertadas, podem vir a ser assassinadas para limpar o nome e a honra da família da vítima ou de sua própria família ${ }^{13}$.

Uma das vantagens da Constituição de 2004 é que, a partir de então, todas as agências e ministérios do Afeganistão possuem um assessor para questão de gênero.

Graças ao trabalho de várias pessoas, afegãs e estrangeiras, algumas leis mudaram no período em que a autora esteve no Afeganistão. Foram treinadas advogadas de defesa para as prisioneiras e passaram a ajudá-las e juízes aprenderam a aplicar a lei. O resultado foi que nacionais e estrangeiros resolveram construir mais um presídio feminino. Há rumores de que outros presídios femininos serão construídos nas províncias. Ou seja, apesar da libertação promovida pelos americanos com relação aos talibãs, mais e mais mulheres afegãs continuam indo para a prisão pelos mesmos velhos "crimes"14.

\footnotetext{
${ }^{13}$ JONNES, Ann. Cabul no inverno: vida sem paz no Afeganistão. São Paulo: Novo Conceito, 2006, p. 143.

${ }_{14}$ JONNES, Ann. Cabul no inverno: vida sem paz no Afeganistão. São Paulo: Novo Conceito, 2006, p. 211.
}

Revista Brasileira de Direito Internacional, Curitiba, v.6, n.6, jul./dez.2007 